\title{
Spontaneous rectus sheath haematoma caused by warfarin-induced overanticoagulation
}

\author{
Takahisa Fujikawa, ${ }^{1}$ Masahide Kawato, ${ }^{2}$ Akira Tanaka ${ }^{1}$ \\ ${ }^{1}$ Department of Surgery, Kokura Memorial Hospital, Kitakyushu, Fukuoka, Japan; \\ 2Department of Cardiovascular Surgery, Kokura Memorial Hospital, Kitakyushu, Fukuoka, Japan
}

Correspondence to Dr Takahisa Fujikawa, fujikawa-t@kokurakinen.or.jp

\section{DESCRIPTION}

A 45-year-old female, receiving long-term warfarin therapy for the past 9 years after undergoing Bentall's operation and aortic arch replacement for dissective aortic aneurysm and annulo-aortic ectasia, developed an increasingly severe lower abdominal pain and visited the emergency department. She received the last pill of warfarin on the day of her presentation in the emergency room, but she denied any abdominal physical trauma or lifting any heavy objects the night before or on the day of her presentation in the emergency room. She had been receiving several antihypertensives for hypertension and her recent blood pressure was stable. She did not have any chronic coughing or previous history of laparotomy.

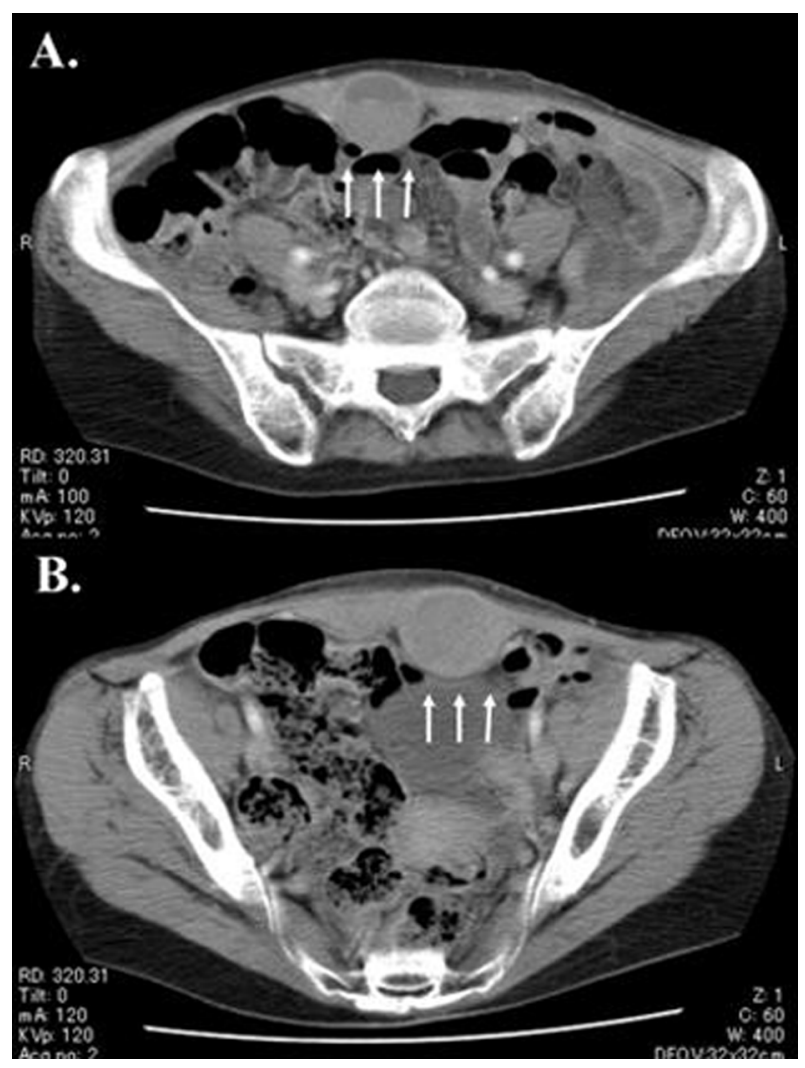

Figure 1 CT scan demonstrated $5 \mathrm{~cm}$ sized hyperdense masses in right (A) and left (B) side of the inferior rectus (arrows), suggesting bilateral rectus sheath haematomas.
On examination, her body mass index was $18.9 \mathrm{~kg} / \mathrm{m}^{2}$, and her temperature, blood pressure, and pulse were within normal parameters. Abdominal examination revealed severe tenderness and rebound tenderness in the lower abdomen. Before this episode, her international normalised ratio was consistently within therapeutic range (2.0-3.0), but it was elevated at $>4.5$ on admission. Other blood indices were normal. CT of the abdomen showed a $5 \mathrm{~cm}$-sized hyperdense masses in the lower half of the bilateral inferior rectus, suggesting rectus sheath haematoma (RSH), without evidence of any other intra-abdominal lesions (figure 1). Management was conservative, consisting of bed rest, analgesics and infusion of vitamin $\mathrm{K}$ and cessation of warfarin. The patient soon recovered and warfarin therapy was restarted without complication. She was discharged home 9 days postadmission. Various bleeding complications are commonly associated with warfarin such as gastrointestinal bleeding or retroperitoneal haematoma. ${ }^{1}{ }^{2} \mathrm{RSH}$ can also result from warfarin-induced overanticoagulation. ${ }^{3} \quad 4$ Predisposing factors for RSH include anticoagulant use, hypertension, obesity, previous abdominal surgery and coughing. ${ }^{3}$ In the current case, the patient had no other concerning factors except for controlled hypertension, and there is probably a true association linking RSH to warfarin (score of 8 according to Naranjo algorithm, ${ }^{5}$ and suggestive reasons for this association are the temporal relationship and pharmacological time plausibility, positive dechallenge, and all other possible causes for RSH being ruled out). $\mathrm{RSH}$ is a relatively uncommon disease and can be misdiagnosed as an acute abdomen and lead to unnecessary operations. ${ }^{3} 4$ The perforating branches of the inferior epigastric artery running in the preperitoneal fat may rupture, causing a large haematoma spreading in the looser rectus sheath space. Non-invasive imaging modalities including high resolution CT scan are the key to establish its early diagnosis. An index of high suspicion and early diagnosis is mandatory to make the correct diagnosis and avoid unnecessary exploratory laparotomy.

Competing interests None.

Patient consent Obtained.

\section{REFERENCES}

1. Wilson RH, Mulholland C, Mackle EJ, et al. The need for closer control of warfarin therapy. J R Coll Surg Edinb 1994;39:171-3. 


\section{BMJ Case Reports}

2. Phillips S, Barr A, Wilson E, et al. Two cases of retroperitoneal haematoma caused by interaction between antibiotics and warfarin. Emerg Med J 2006. doi: 10.1136/emj.2004.016345.

3. Takemoto F, Okuda I, Sawa N, et al. Rectus sheath haematoma in a patient receiving haemodialysis. BMJ Case Reports 2010. doi:10.1136/ bcr.12.2009.2527.
4. Kelly M, Moran J, Byrne S. Formation of rectus sheath hematoma with antibiotic use and warfarin therapy: a case report. Am J Geriatr Pharmacother 2005;3:266-9.

5. Naranjo CA, Busto U, Sellers EM, et al. A method for estimating the probability of adverse drug reactions. Clin Pharmacol Ther 1981;30:239-45.

This pdf has been created automatically from the final edited text and images.

Copyright 2011 BMJ Publishing Group. All rights reserved. For permission to reuse any of this content visit http://group.bmi.com/group/rights-licensing/permissions.

BMJ Case Report Fellows may re-use this article for personal use and teaching without any further permission.

Please cite this article as follows (you will need to access the article online to obtain the date of publication).

Fujikawa T, Kawato M, Tanaka A. Spontaneous rectus sheath haematoma caused by warfarin-induced overanticoagulation . BMJ Case Reports 2011;10.1136/bcr.07.2011.4533, date of publication

Become a Fellow of BMJ Case Reports today and you can:

- Submit as many cases as you like

- Enjoy fast sympathetic peer review and rapid publication of accepted articles

- Access all the published articles

- Re-use any of the published material for personal use and teaching without further permission

For information on Institutional Fellowships contact consortiasales@bmjgroup.com

Visit casereports.bmj.com for more articles like this and to become a Fellow 